\title{
ODDZIAŁYWANIE PRAW PODSTAWOWYCH NA STOSUNKI MIĘDZY PODMIOTAMI PRYWATNYMI W SZWAJCARII
}

Monika Florczak-Wątor

1. WSTĘP

$\mathrm{D}$ yskusja wokół problemu horyzontalnego działania praw podstawowych w szwajcarskiej doktrynie prawa i orzecznictwie sądowym została zapoczątkowana po II wojnie światowej. Pozostawała ona pod dużym wpływem koncepcji formułowanych w tym zakresie w Niemczech przez przedstawicieli tamtejszej judykatury i piśmiennictwa. W toku owej dyskusji utrwalił się pogląd, powszechnie dziś w Szwajcarii podzielany, zgodnie $\mathbf{z}$ którym prawa podstawowe powinny być uwzględniane w stosunkach między podmiotami prywatnymi, przy czym obowiązek zagwarantowania im horyzontalnej skuteczności ciąży na państwie i jego organach.

Wyrazem aprobaty dla tego poglądu było wprowadzenie do obecnie obowiązującej Konstytucji Federalnej Konfederacji Szwajcarskiej ${ }^{1}$ art. 35, który wprost odnosi się do kwestii horyzontalnego działania praw podstawowych. Zgodnie $z$ tym przepisem prawa podstawowe

Konstytucja Federalna Konfederacji Szwajcarskiej (Bundesverfassung der Schweizerischen Eidgenossenschaft, dalej: BV lub Konstytucja Szwajcarii z 1999 r.) została przyięta przez Zgromadzenie Federalne 18 grudnia 1998 r., zatwierdzona przez Naród w drodze referendum 18 kwietnia 1999 r., weszła w życie 1 stycznia $2000 \mathrm{r}$. 
muszą być urzeczywistniane w całym porządku prawnym, zaś każdy, kto wykonuje zadania państwowe jest nimi związany, jak również jest zobowiązany przyczyniać się do ich realizacji. Przepis ten zobowiązuje też władze publiczne do dbania o to, by prawa podstawowe, o ile do tego się nadają, były stosowane także między podmiotami prywatnymi.

Obecnie zatem teza, zgodnie $\mathbf{z}$ którą prawa podstawowe oddziałują na stosunki między podmiotami prywatnymi, nie jest w zasadzie w szwajcarskiej doktrynie prawa kontestowana. Pytanie dotyczy zatem nie tego "czy", lecz tego "w jaki sposób" i „w jakim zakresie" można mówić o owym wymiarze horyzontalnym².

\section{PRAWA PODSTAWOWE W KONSTYTUCJI SZWAJCARII}

Z 1999 ROKU

Konstytucja Szwajcarii z 1999 r. zawiera obszerny rozdział poświęcony problematyce praw jednostki, w którego treści widoczne są nawiązania nie tylko do Konstytucji RFN z 1949 r., ale również Europejskiej Konwencji o ochronie praw człowieka i podstawowych wolności. W rozdziale tym wyodrębniono podrozdziały dotyczące praw podstawowych (art. 7-art. $36 \mathrm{BV}$ ), praw obywatelskich i politycznych (art. 37 - art. 40 BV) oraz celów socjalnych (art. $40 \mathrm{BV}$ ). Te ostatnie nie sa jednak tożsame z prawami socjalnymi. Szwajcarska doktryna prawa rozróżnia bowiem cele socjalne (Sozialzele) oraz socjalne prawa podstawowe (Sozialgnundrechte), uregulowane $w$ pierwszym ze wspomnianych podrozdziałów. Są to prawa wyrażone przy użyciu formuły roszczenia (Anspruch), których przedmiotem jest żądanie od państwa wsparcia jednostki znajdującej się w potrzebie. Do

2 Tak problem formułowany jest $w$ doktrynie prawa, zob. P. Egli, Drittwirkung von Grundrechten. Zugleich ein Beitrag zur Dogmatik der grundrechtlichen Schutzpflichten im Schweizer Recht. Zürich 2002, s. 141 i 197; G. Müller, Die Drittwirkung der Grundrechte, Schweizerisches Zentralblatt für Staats- und Gemeindeverwaltung, 1978, Nr. 79, s. 234. 
socjalnych praw podstawowych zalicza się zatem prawo do pomocy i opieki ze strony państwa w trudnych sytuacjach (art. $12 \mathrm{BV}$ ), prawo do nauczania na poziomie podstawowym (art. $19 \mathrm{BV}$ ) oraz prawo do bezpłatnej pomocy prawnej (art. 29 ust. 3 BV). W doktrynie wskazuje się, że owa kategoria socjalnych praw podstawowych nie powinna być rozszerzana poza te prawa, które wyraźnie jako takie statuowane są przez przepisy konstytucyjne'. W przeciwieństwie do socjalnych praw podstawowych, cele socjalne wymienione $w$ art. 40 BV nie są źródłem praw podmiotowych, stąd - zgodnie $z$ art. 41 ust. 4 BV - nie mogą być $z$ nich bezpośrednio wywodzone roszczenia o świadczenia ze strony państwa.

Szwajcarska doktryna prawa w kwestii rozumienia praw podstawowych $w$ dużym stopniu opiera się na ustaleniach niemieckiej doktryny prawa, zaś szwajcarski Sąd Federalny często nawiązuje do rozstrzygnięć niemieckiego Federalnego Sądu Konstytucyjnego. Tak jak w Niemczech, również w Szwajcarii wskazuje się na podwójny wymiar praw podstawowych. $Z$ jednej strony sa one prawami podmiotowymi, które przysługują osobie uprawnionej w jej relacjach z państwem i innymi podmiotami (również podmiotami prywatny. mi). W tym wymiarze wskazuje się, że prawa podstawowe stanowią podstawę roszczeń zarówno o obronę przed działaniami państwa (Abwehransprüche), o świadczenie ze strony państwa (Leistungsansprüche), jak i o ochronę przed działaniami podmiotów niepaństwowych (Schutzansprüche) ${ }^{4}$. Z drugiej strony są one wytycznymi dla działań organów władzy publicznej, zarówno tych stanowiących prawo, jak i je stosujących. U podstaw tych praw leżą bowiem określone wartości uznane za cenne i wymagające ochrony ze strony państwa. Funkcja praw podstawowych nie wyczerpuje się zatem w tym, że ustanawiają one granice dla działalności państwa i chronią obywateli przed

3 T. Fleiner-Gerster, A. Misic, N. Töpperwien, Swiss Constitutional Law, Bern 2005, S. 154.

4 R. Kiener, W. Kälin, Grundrechte, Bern, 2007, s. 31, Stampflis juristische Lehrbücher, G. Biaggini, T. Gächter, R. Kiener (Hrsg.). Staatsrecht, Zürich 2011, S. 420. 
jego ingerencją, choć nie ma wątpliwości, że ta ich funkcja obronna ma charakter pierwszoplanowy'. Prawa podstawowe są jednak również obiektywnymi zasadami przenikającymi cały porządek prawny ${ }^{6}$. Ich adresatami w tym zakresie są władze publiczne na wszelkich polach działania państwa, osoby prawne prawa publicznego oraz osoby wykonujące zadania państwowe?. W tym ostatnim wypadku chodzi o osoby fizyczne i prawne prawa prywatnego, które związane są prawami podstawowymi $z$ mocy art. 35 ust. 2 BV.

Zaprezentowany wyżej pogląd dotyczący natury praw podstawowych jest również od lat obecny $w$ orzecznictwie szwajcarskiego Sądu Federalnego, który podkreśla, że prawa podstawowe są nie tylko prawami podmiotowymi jednostki zapewniającymi egzekwowalną ochronę przed zagrożeniami ze strony państwa (individuelles Abwehrrecht), ale również postanowieniami prawa przedmiotowego (objektiv-rechtlicher Gehalt) przenikającymi cały porządek prawny ${ }^{8}$.

\section{KONSTYTUCYJNA REGULACJA STOSUNKÓW HORYZONTALNYCH}

Konstytucja Szwajcarii z 1999 r. w niewielkim stopniu reguluje typowe stosunki horyzontalne, czyli takie, które łączą podmioty prywatne. Zawiera w tym zakresie przepisy odnoszące się do stosunków pracowniczych, rodzinnych i gospodarczych, przy czym tylko w wypadku tych pierwszych regulacja ta odnosi się bezpośrednio do samych sto-

5 P. Egli, Drittwirkung von Grundrechten, s. 135; R.A. Rhinow, M. Schefer, Schweizerisches Verfassungsrecht, Basel 2009, s. 234; P. Saladin, Grundrechte und Privatrechtsordnung. Zum Streit um die sog. "Drittwirkung" der Grundrechte, "Schweizerische Juristen-Zeitung" 1988, Nr. 15, s. 373.

6 Uwaga nr 4 do art. 35 BV, [w:] G. Biaggini, Bundesverfassung der Schweizerischen Eidgenossenschaft und Auszüge aus der EMRK, den UNO-Pakten sowie dem BGG, Zürich 2007.

7 P. Egli, Drittwirkung von Grundrechten, s. 139.

B Zob. orzeczenia szwajcarskiego Sądu Federalnego: BGE 130 III 353, par. 2.1.1.; BGE 134 I 49, par. 2.4.; BGE 34 I 56, par. 4.4 (dwa ostatnie dotyczą odmowy naturalizacji osób noszących muzułmańskie nakrycia głowy). 
sunków, a nie do obowiązków państwa względem stron tych stosunków. W kwestiach pracowniczych każdemu jest zatem gwarantowane prawo do równego wynagrodzenia za jednakową pracę (art. 8 ust. 3 zd. 3 BV), prawo do zrzeszania się przez pracowników i pracodawców (art. 28 ust. 1 BV), prawo do prowadzenia rokowań i mediacji (art. 28 ust. 3 BV) oraz prawo do strajku (art. 28 ust. 3 BV). W zakresie wolności gospodarczej gwarantuje się każdemu swobodny dostęp do działalności zarobkowej w gospodarce prywatnej i jej swobodne wykonywanie (art. 27 ust. 2 BV). W kwestii stosunków rodzinnych poręczone zostało przez ustrojodawcę prawo do małżeństwa i rodziny (art. 14 BV) oraz przyznane dzieciom i młodzieży prawo do szczególnej ochrony ich nietykalności i do wspierania ich rozwoju (art. 11 BV).

W rozdziale poświęconym prawom podstawowym na określenie owych praw Konstytucja Szwajcarii z 1999 r. używa trzech pojęć: prawo (Recht), wolność (Freiheit) oraz roszczenie (Anspruch). Do pierwszej kategorii praw podstawowych zaliczono np. prawo do życia (Recht auf Leben, art. 10 ust. 1 BV), prawo do wolności osobistej (Recht auf persönliche Freiheit, art. 10 ust. 2 BV), prawo do małżeństwa i rodziny (Recht auf Ehe und Familie, art. 14 BV), prawo petycji (Petitionsrecht, art. $33 \mathrm{BV}$ ) czy prawa polityczne (politische Rechte, art. 34 BV). Z kolei do kategorii praw wolnościowych zaliczono np. wolność sumienia i wyznania (Glaubens- und Gewissensfreiheit, art. 15 BV), wolność słowa i informacji (Meinungs- und Informationsfreiheit, art. 16 BV), wolność prasy, radia i telewizji (Freiheit von Presse, Radio und Fernsehen, art. 17 BV) czy wolność nauki i badań naukowych (Freiheit der wissenschaftlichen Lehre und Forschung, art. 20 BV). Trzecią kategorię praw podstawowych stanowią te, które ustrojodawca nazwał roszczeniami, np. prawo do równego wynagrodzenia za jednakową prace (Anspruch auf gleichen Lohn für gleichwertige Arbeit, art. 8 ust. 3 BV), prawo do pomocy i opieki oraz uzyskania środków niezbędnych do zapewnienia godnej egzystencji (Anspruch auf Hilfe und Betreuung und auf die Mittel, die für ein menschenwürdiges Dasein unerlässlich sind, art. $12 \mathrm{BV}$ ), prawo do bycia wystuchanym przez sąd (Anspruch auf rechtliches Gehör, art. 29 ust. 2 BV). Do tej ostatniej grupy praw - rosz. czeń należą dodatkowo roszczenia o zapewnienie ochrony (Anspruch 
auf Schutz), tj. prawo do szczególnej ochrony nietykalności i zapewnienia rozwoju dzieciom i młodzieży (art. 11 ust. 1 BV), oraz prawo do ochrony przed nadużyciem danych osobowych (art. 13 ust. 2 BV). Choć wyróżnienie tych trzech kategorii praw podstawowych jest rozwiązaniem oryginalnym, które nie występuje np. Konstytucji RFN', to jednak nie ma ono większego znaczenia $z$ punktu widzenia analizowanej problematyki horyzontalnego działania praw podstawowych. W szczególności skuteczność horyzontalna działania danego prawa nie jest uzależniana od zaliczenia go do konkretnej kategorii prawa (Recht), wolności (Freiheit) lub roszczenia (Anspruch).

Przepisem, który w literaturze szwajcarskiej często przywołuje się w rozważaniach dotyczących horyzontalnego działania praw podstawowych jest art. 8 BV. Statuuje on zasadę równości wobec prawa (ust. 1) oraz zakaz dyskryminacji (ust. 2), a ponadto zobowiązuje państwo do zagwarantowania w swoim ustawodawstwie tego, by zasada równości była faktycznie realizowana w odniesieniu do kobiet i mężczyzn oraz osób niepełnosprawnych. Zgodnie $z$ art. 8 ust. 3 BV to ustawa powinna zapewnić prawne i rzeczywiste równouprawnienie kobiet i mężczyzn w rodzinie, w kształceniu i w pracy, zaś stosownie do treści art. 8 ust. 4 BV ustawa powinna określić środki umożliwiające wyeliminowanie pokrzywdzenia osób niepełnosprawnych. Równość nie tylko prawna, ale i faktyczna ma być zatem kształtowa. na przez państwo $w$ drodze stosownych ustaw regulujących stosunki horyzontalne. Szczególne znaczenie art. 8 BV wyraża się jednak nie tyle w tym, że zobowiązuje on państwo do zagwarantowania realizacji zasady równości $w$ stosunkach między podmiotami prywatnymi, ile $\mathbf{w}$ tym, że na te ostatnie w pewnym zakresie nakłada analogiczny obowiązek do tego, który ciąży na państwie. Bezpośrednia horyzon. talna skuteczność przypisywana jest bowiem art. 8 ust. 3 zd. 3 BV, z którego wynika, że mężczyzna i kobieta mają prawo do równego wynagrodzenia za taką samą pracę. Przepis ten zawiera zatem treść

9 W Konstytucji RFN z 1949 r. pojęcie roszczenia (Anspruch) występuje w art. 6 ust. 4 GG (prawo matki do ochrony i opieki ze strony państwa) oraz w art. 103 ust. 1 GG (prawo do bycia wystuchanym przez sąd). 
normatywną tożsamą $\mathbf{z}$ tą, którą wcześniej zawierał art. 4 ust. 2 Konstytucji z 1874 r. i któremu również przypisywano bezpośrednie horyzontalne działanie.

\section{ART. 35 BV I JEGO GENEZA}

Od wejścia w życie obecnie obowiązującej Konstytucji Szwajcarii z 1999 r. dyskusja nad problemem horyzontalnego działania praw podstawowych toczy się głównie wokół jej art. 35. Przepis ten składa się z trzech ustępów, które w sumie mają dać odpowiedź na pytania o to, w jaki sposób i w jakim zakresie prawa podstawowe działają w stosunkach horyzontalnych. Ustęp pierwszy art. 35 BV stanowi, że prawa podstawowe muszą być urzeczywistniane w całym porządku prawnym. Zgodnie $z$ ustępem drugim, każdy, kto wykonuje zadania państwowe, jest związany prawami podstawowymi i jest zobowiązany przyczyniać się do ich realizacji. I w końcu ustęp trzeci zobowiązuje władze publiczne do dbania o to, by prawa podstawowe, o ile do tego się nadają, także między podmiotami prywatnymi były stosowane. Należy zauważyć, że art. 35 Konstytucji usytuowany jest w podrozdziale dotyczącym praw podstawowych. Taka systematyka regulacji konstytucyjnej pozwala na stwierdzenie, że przepis ten nie znajduje zastosowania do praw politycznych i celów socjalnych, gdyż oba te zagadnienia uregulowane są w kolejnych podrozdziałach tego aktu prawnego.

Art. 35 BV nie miał swojego odpowiednika w Konstytucji Szwajcarii z $1874 \mathrm{r}$. W doktrynie podkreśla się jednak, że treść tego przepisu wyraża pewne poglądy, które ukształtowały się i utrwaliły w szwajcarskiej doktrynie prawa i judykaturze pod rządami poprzednio obowiązującej ustawy zasadniczej ${ }^{10}$. Po II wojnie światowej pod wpływem niemieckiej doktryny i judykatury rozważano możliwość stosowania w szwajcarskich realiach konstytucyjnych koncepcji bezpośredniego i pośredniego horyzontalnego działania praw podstawo-

10 P. Egli, Drittwirkung von Grundrechten, s. 151. 
wych, a później również koncepcji obowiązków ochronnych państwa w stosunkach horyzontalnych" ${ }^{11}$. Bezpośredni skutek horyzontalny przypisywano na gruncie Konstytucji Szwajcarii z 1874 r. dwóm jej przepisom. Pierwszym z nich był art. 49 ust. 3, który przyznawał osobom mającym władzę rodzicielską lub opiekuńczą prawo do religijnego wychowania (zgodnie $\mathbf{z}$ własnymi przekonaniami) dzieci w wieku do lat 16 . Za horyzontalną skutecznością tego przepisu opowiadano się zarówno w doktrynie prawa, jak i w orzecznictwie ${ }^{12}$. Drugim przepisem był art. 4 ust. 2, który przyznawał kobiecie i mężczyźnie prawo do równego wynagrodzenia za tę samą pracę. Wskazywano, że ten ostatni przepis przyznaje każdemu indywidualne roszczenie, które może być sądownie dochodzone także w prywatnoprawnych stosunkach pracowniczych ${ }^{13}$. Stąd też przyjmowano, że można mu przypisać bezpośrednie horyzontalne działanie ${ }^{14}$. $Z$ kolei obowiązki ochronne państwa w stosunkach horyzontalnych wywodzono $z$ art. 2 Konstytucji Szwajcarii z 1874 r., który jako jeden z celów państwa wskazywał ochronę praw i wolności obywateli. Problem obowiązków ochronnych państwa rozważano również w kontekście przepisów statuujących konkretne prawa podstawowe ${ }^{15}$. Do tych ostatnich należały przepisy, które stanowiły o prawach "gwarantowanych" przez państwo, takich jak prawo własności (art. 22b), wolność działalności gospodarczej (art. 31), swobodne wykonywanie działalności liturgicznej (art. 50), wolność prasy (art. 55), prawo petycji (art. 57). Ponadto "pod ochronę państwa" poddano prawo do małżeństwa (art. 54), zaś za prawo podstawowe o charakterze nienaruszalnym uznawano wolność sumienia i religii (art. 49).

\footnotetext{
$"$ P. Saladin, Grundrechte und Privatrechtsordnung, s. 384.

12 J.P. Müller, Zur sog. subjektiv- und objektivrechtlichen Bedeutung der Grundrechte: rechtsvergleichende Bemerkungen aus Schweizer Sicht, "Der Staat" 1990 , Bd. 29. H. 1, s. 39; P. Sala din, Die Kunst der Verfassungsemeuerung: Schriften zur Verfassungsreform 1968-1996, Basel 1998, s. 91; ide m, Grundrechte und Privatrechtsordnung, s. 376.

13 J.P. Müller, Elemente einer schweizerischen Grundrechtstheorie, Bern 1982, s. 83 .

${ }^{14}$ I dem, Zur sog. subjektiv- und..., s. 39; P. Sa la di in, Die Kunst..., s. 91.

is Idem, Grundrechte und Privatrechtsordnung, s. 376.
} 
W ówczesnej szwajcarskiej doktrynie prawa pojawiały się głosy krytykujące podstawowe założenia koncepcji horyzontalnego działania praw podstawowych, jednak znajdowały się one $\mathbf{w} z$ decydowanej mniejszości. Tylko nieliczni przedstawiciele doktryny twierdzili, że prawa podstawowe nie mają żadnego znaczenia dla stosunków miedzy podmiotami prywatnymi, a nawet, że nie nadają się do stosowania $w$ relacjach horyzontalnych ${ }^{16}$.

Szczególne zasługi w propagowaniu koncepcji horyzontalnego działania praw podstawowych miał Jörg P. Müller, który zaadoptował do szwajcarskich realiów konstytucyinych ustalenia niemieckiej doktryny i judykatury w tej kwestii. Wskazywał on, że prawa podstawowe zasadniczo mają horyzontalny wymiar, choć nie wszystkie one nadają się do stosowania w stosunkach horyzontalnych, jak również nie wszystkie stosunki horyzontalne $w$ jednakowym stopniu wymagaja uwzględniania praw podstawowych ${ }^{17}$. Jeśli bowiem są to stosunki między dwoma równorzędnymi podmiotami, to nie wymagają one odwoływania się do praw podstawowych $w$ takim stopniu, jak ma to miejsce w wypadku stosunków, w których jedna ze stron posiada przewagę nad drugą (np. stosunki pracownicze czy stosunki korporacyine). Tam, gdzie prawa podstawowe nadają się do zastosowania w nierównorzędnych stosunkach prawnych między podmiotami prywatnymi, pojawia się $\mathbf{z}$ kolei konieczność ustalenia sposobu ich urzeczywistniania. W tym zakresie w pierwszej kolejności to ustawodawca zobowiązany jest do ukształtowania stosunków prywatnoprawnych $\mathbf{z}$ uwzględnieniem praw podstawowych. W dalszej kolejności sędzia zobowiązany jest do uwzględniania praw podstawowych w procesie wykładni i konkretyzacji norm prawa prywatnego, w szczególności klauzul generalnych, zwrotów niedookreślonych. Jeżeli jednak normy prawa prywatnego $\mathrm{w}$ ogóle nie zapewniają ochrony prawu podstawowemu lub ochronę taką gwarantują w niepełnym zakresie, wówczas sędzia orzekając $w$ takim stanie prawnym, jest uprawniony,

16 Poglądy doktryny szwajcarskiej sprawozdawczo przedstawia J.P. Müller, Elemente einer schweizerischen..., s. 81 i nast.

17 Ibidem, s. 85. 
a wręcz zobowiązany do bezpośredniego uwzględniania praw podstawowych. Zdaniem J.P. Müllera bezpośrednie horyzontalne działanie praw podstawowych może mieć miejsce wówczas, gdy konstytucja wyraźnie je przewiduje, a nakaz uwzględniania praw podstawowych jest uzasadniony.

5. HORYZONTALNA SKUTECZNOŚĆ PRAW PODSTAWOWYCH W ŚWIETLE ART. 35 BV

Zgodnie $z$ art. 35 ust. 1 BV prawa podstawowe muszą być urzeczywistniane w całym porządku prawnym. Przepis ten odwołuje się do koncepcji praw podstawowych jako fundamentalnych rozstrzygnięć aksjologicznych, które tworzą obiektywny (wyrażony przez normy prawa przedmiotowego) porządek wartości ${ }^{18}$. Choć art. 35 ust. 1 BV nie wskazuje expressis verbis podmiotu zobowiązanego do owego urzeczywistniania praw podstawowych, to nie ma wątpliwości, że podmiotem tym są organy władzy publicznej. Prawa podstawowe są dla nich wiążącymi wskazówkami, wytycznymi dla działań podejmowanych w sferze stanowienia i stosowania prawa.

Obowiązek urzeczywistniania praw podstawowych w całym porządku prawnym ciąży w pierwszej kolejności na ustawodawcy, który powinien je uwzględniać, stanowiąc przepisy regulujące stosunki między podmiotami prywatnymi. Związanie ustawodawcy prawami podstawowymi oznacza, że ma on obowiązek powstrzymywać się od stanowienia prawa, które naruszałoby owe prawa podstawowe, ale również obowiązek podejmowania pozytywnych działan dla urzeczywistniania tych praw w stosunkach między podmiotami prywatnymi ${ }^{19}$. W dalszej kolejności obowiązek urzeczywistniania praw podstawowych w całym porządku prawnym spoczywa na organach

\footnotetext{
18 Uwaga nr 4 do art. 35 BV, [w:] G. Biaggini, Bundesverfassung der Schweizerischen Eidgenossenschaft...

19 T. Göksu, Drittwirkung der Grundrechte im Bereich des Persönlichkeitsschutzes, "Schweizerische Juristen-Zeitung" 2002, Nr. 4, s. 91.
} 
stosujących prawo, w szczególności zaś na sądach, które prawa podstawowe powinny uwzględniać w procesie wykładni pojęć niedookreślonych i klauzul generalnych ${ }^{20}$. Obowiązki ochronne ciążą nie tylko na sądach, ale również na organach administracyjnych czy służbach porządkowych ${ }^{21}$.

Art. 35 ust. 2 BV wprowadza zasadę, zgodnie z którą każdy, kto wykonuje zadania państwowe, jest związany prawami podstawowymi, jak również jest zobowiązany przyczyniać się do ich realizacji. Przepis ten rozszerza zakres podmiotów zobowiązanych $z$ tytułu praw podstawowych poza organy państwa, o których mowa w art. 35 ust. 1 BV. Odnosi się on bowiem wyraźnie do podmiotów niepaństwowych, a konkretnie podmiotów prywatnych, które wykonują zadania państwowe. W doktrynie prawa podnosi się wątpliwości co do zasadności użycia w tym przepisie pojęcia "zadanie państwowe" (staatliche Aufgabe), wskazując, że po przekazaniu zadania do realizacji podmiotowi prywatnemu traci ono swój państwowy charakter ${ }^{22}$. Niektórzy przedstawiciele doktryny twierdzą, że bardziej zasadne byłoby użycie w tym przepisie pojęcia "zadanie administracyjne” (Venvaltungsauf. gaben), którym posługuje się art. 178 ust. 3 BV. Przepis ten zadaniami administracyjnymi nazywa te, które w drodze ustawy państwo może przekazać do realizacji podmiotom prywatnym usytuowanym poza strukturą administracji publicznej. Inni przedstawiciele doktryny stanowisko to kwestionują, podnosząc, że art. 35 ust. 2 BV nie odnosi się do sytuacji, gdy państwo przekazuje podmiotowi prywatnemu zadanie, które tym samym traci państwowy charakter (Aufgabenprivatisierung), lecz dotyczy sytuacji, gdy podmiotowi prywatnemu przekazano jedynie wykonywanie tego zadania (Organisationsprivatisierung) ${ }^{23}$. Wszyscy zgodnie wskazują jednak na potrzebę szerokiego rozumienia pojęcia zadania państwowego, o którym mowa w art. 35 ust. 2

\footnotetext{
20 Ibidem, s. 92.

${ }_{21}$ R. Kiener, W. Kälin, Grundrechte, s. 35.

22 R.A. Rhinow, M. Schefer, Schweizerisches..., s. 232.

23 G. Biaggini, T. Gächter, R. Kiener (Hrsg.), Staatsrecht, s. 423.
} 
BV $^{24}$. Państwo, przekazując zadania państwowe podmiotowi prywatnemu, nie może zwolnić się od obowiązku respektowania praw podstawowych przy ich wykonywaniu. Stąd zobowiązane jest tak określić warunki przekazania tych zadań (np. koncesji, zezwolenia), a następnie własne warunki nadzoru nad ich realizacją, by zapewnić poszanowanie praw podstawowych przez podmiot prywatny, który owe zadania będzie realizował ${ }^{25}$.

Kolejny ustęp art. 35, ti. ustęp trzeci, zobowiązuje władze publiczne do dbania o to, by prawa podstawowe, o ile do tego się nadaja, także między podmiotami prywatnymi były stosowane. Przepis ten nie nakłada zatem bezpośrednio na podmioty prywatne obowiązku respektowania praw podstawowych innych podmiotów prywatnych, choć jednocześnie zobowiązuje państwo do czuwania nad tym, by miało miejsce poszanowanie tych praw $w$ stosunkach horyzontalnych. W doktrynie wskazuje się na szeroki zakres przedmiotowy art. 35 ust. $3 \mathrm{BV}^{26}$. Przepis ten zobowiązuje władze publicznie nie tylko do dbania o to, by prawa podstawowe były w prawie prywatnym uwzględniane, ale by były stosowane między podmiotami prywatnymi. Prawa te powinny być respektowane nie tylko w stosunkach horyzontalnych regulowanych przez prawo prywatne. Obowiązek władz państwowych, o którym mowa w art. 35 ust. 3 BV, jest bowiem szerzej sformułowany i dotyczy wszelkich stosunków prawnych, również tych z zakresu prawa karnego czy administracyjnego.

Nie do końca jest jasna relacja między ustępem 1 i 3 analizowanego art. 35 BV. Jedni bowiem wskazują, że art. 35 ust. 1 ustanawia pewien ogólny obowiązek (obowiązek urzeczywistniania praw podstawowych), który art. 35 ust. 3 konkretyzuje w odniesieniu do stosunków horyzontalnych ${ }^{27}$. Ządanie urzeczywistniania praw podstawowych przybiera $\mathbf{w}$ takiej sytuacji postać żądania ich ochrony.

24 T. Fleiner-Gerster, A. Misic, N. Töpperwien, Swiss Constitutional..., S. 208.

25 BGE 127 I 84, 90; R.A. Rhinow, M. Schefer, Schweizerisches..., s. 233.

26 P. Egli, Drittwirkung von Grundrechten, s. 195.

27 Uwaga nr 7 do art. 35 BV, [w:] G. Biaggini, Bundesverfassung der Schweizerischen Eidgenossenschaft... 
Państwo nie może bezczynnie przyglądać się, gdy prawa podstawowe są zagrożone, niezależnie od tego, czy zagrożenie to pochodzi ze strony organów państwowych, czy podmiotów prywatnych. Inni z kolei przyjmują, że art. 35 ust. 1 BV działa jedynie w stosunkach wertykalnych, podczas gdy art. 35 ust. 3 BV działanie praw podstawowych rozciąga dodatkowo na stosunki horyzontalne. $\mathrm{Z}$ tego ostatniego przepisu miałby wynikać zatem obowiązek dalej idący, o charakterze pozytywnym, a mianowicie obowiązek dbania o to, by prawa podstawowe, o ile do tego się nadaja, były stosowane także między podmiotami prywatnymi.

\section{KONCEPCJE BEZPOŚREDNIEGO I POŚREDNIEGO HORYZONTALNEGO DZIAEANIA PRAW PODSTAWOWYCH I ICH APLIKACJA W SZWAJCARII}

Art. 35 ust. 3 Konstytucji Szwajcarii z 1999 r. wyklucza możliwość przyjęcia jako zasady koncepcji bezpośredniego horyzontalnego działania praw podstawowych ${ }^{28}$. W doktrynie prawa wskazuje się, że koncepcja ta może znaleźć zastosowanie jedynie wyjątkowo, a mianowicie wówczas, gdy bezpośrednie horyzontalne działanie prawa podstawowego wyraźnie wynika z przepisu konstytucyjnego ${ }^{29}$. Jako przykład tego rodzaju regulacji konstytucyjnej powszechnie wskazuje się art. 8 ust. 3 zd. 3 BV, zgodnie z którym kobieta i mężczyzna mają prawo do jednakowego wynagrodzenia za taką samą pracę ${ }^{30}$. Pojawiają się jednak głosy, że bezpośrednie horyzontalne działanie statuuja również dwa inne przepisy, tj. art. 17 ust. 3 BV, który chroni tajemnicę dziennikarską, oraz art. 28 ust. 3 BV, który wskazuje warunki do-

\footnotetext{
$28 \quad$ R. Kiener, W. Kälin, Grundrechte, s. 47.

29 P. Egli, Drittwirkung von Grundrechten, s. 154; W. Haller, A. Kölz, Allgemeines Staatsrecht. Ein Grundriss, Basel 2004, s. 319.

so Ibidem, s. 320; P. Egli, Drittwirkung von Grundrechten, s. 140 i 142; R.A. Rhinow, M. Schefer, Schweizerisches..., s. 234; T. Fleiner-Gerster, A. Misic, N. Töpperwien, Swiss Constitutional..., s. 209; G. Biaggini, T. Gächter, R. Kiener (Hrsg.), Staatsrecht, s. 424; R. Kiener, W. Kälin, Grundrechte, s. $4^{8}$.
} 
puszczalności strajku i lokautu. W doktrynie prawa podnosi się, że w tych trzech wymienionych wyżej przepisach chodzi o bezpośrednie, nakazane przez Konstytucję Szwajcarii z 1999 r. urzeczywistnianie praw podstawowych $\mathbf{w}$ stosunkach między podmiotami prywatnymi, które podlega regulacjom prawa prywatnego ${ }^{31}$. De facto chodzi za. tem o przypadki objęte zakresem normowania wynikającym $z$ art. 35 ust. 2 BV.

Pogląd wykluczający co do zasady bezpośrednie horyzontalne działanie praw podstawowych prezentowany jest również $\mathbf{w}$ orzecznictwie Sądu Federalnego. Początkowo dopuszczał on bezpośrednią skuteczność niektórych praw podstawowych, takich jak wolność religii czy wolność słowa ${ }^{32}$. W literaturze przedmiotu na potwierdzenie tej tezy podawane jest orzeczenie z 23 sierpnia 1878 r., w którym Sąd Federalny uznał horyzontalne działanie wolności religijnej w stosunkach między małżonkami ${ }^{33}$. W tej sprawie małżeństwo zostało rozwiązane przez rozwód orzeczony na żądanie męża $z$ powodu zmiany przez żonę wyznania. Rozstrzygnięcie to zostało zaskarżone przez żonę, która domagała się orzeczenia separacji. Sąd drugiej instancji stwierdził, że rozbieżność poglądów religijnych nie jest okolicznością przesądzającą rozkład pożycia małżeńskiego. Rozważał zatem bezpośrednie działanie wolności religii w stosunkach horyzontalnych. W Konstytucji Szwajcarii z 1999 r. wolność ta ujęta jest w art. 15, zgodnie $\mathbf{z}$ którym każdy ma prawo wstępowania do wspólnoty wyznaniowej i należenia do niej oraz prawo pobierania nauki religii (ust. 3), a także nikt nie może być zmuszany do wstąpienia do wspólnoty wyznaniowej lub należenia do niej oraz do wykonywania praktyk religijnych i pobierania nauki religii (ust. 4). W końcowej części tego przepisu wolność religii jest zatem sformułowana od strony negatywnej, co mogłoby sugerować, że ma ona absolutny charakter. Pogląd

\footnotetext{
"R.A. Rhinow, M. Schefer, Schweizerisches..., s. 235.

32 Co do przykładów orzeczeń zob. P. Egli, Drittwirkung von Grundrechten, S. 143-144; J.P. Müller, Elemente einer schweizerischen..., s. 83-84; P. Saladin, Grundrechte im Wandel, Bern 1982, s. 311-318.

33 BGE 4 S. 434 "Glaubensfreiheit in der Ehe". Skan tego orzeczenia jest dostępny na stronie: http://servat.unibe.ch/dfr/pdf/c1004434.pdf, 22 maja 2015.
} 
o bezpośrednim horyzontalnym działaniu wolności religii został jednak przez Sąd Federalny ostatecznie odrzucony jeszcze na gruncie poprzednio obowiązującej Konstytucji z 1874 r. W orzeczeniu z 14 lutego 1992 r. w sprawie Info-Sekta, stwierdził on, że wolność religii chroni jednostkę i wspólnotę religijną przed bezprawną ingerencją ze strony państwa. Nie działa ona natomiast bezpośrednio przeciwko podmiotom prywatnym. Horyzontalne działanie wolności religii ma jedynie wymiar pośredni w tym sensie, że wolność ta powinna być uwzględniana w procesie interpretacji otwartych klauzul występujących $\mathbf{w}$ prawie prywatnym i prawie karnym ${ }^{34}$.

Pogląd, zgodnie $z$ którym art. 35 ust. 3 BV nakazuje odrzucenie - co do zasady - koncepcji bezpośredniego horyzontalnego działania praw podstawowych i przyjęcie koncepcji działania pośredniego, nie budzi wątpliwości w szwajcarskiej doktrynie prawa ${ }^{35}$. Obie te koncepcje sa przy tym rozumiane tak, jak zostały one ukształtowane przez niemiecką doktrynę i judykaturę. W literaturze pojawił się jednak ciekawy pogląd, wskazujący na to, że koncepcje niemieckie nie są w Szwajcarii jedynie powielane, lecz twórczo przetwarzane. Patricia Egli, która problematyce horyzontalnego działania praw podstawowych poświęciła obszerną monografię, stara się wykazać, że w oparciu o dwie wspomniane wcześniej koncepcje horyzontalnego działania praw podstawowych szwajcarska doktryna prawa skonstruowała własną koncepcję pośredniczącego horyzontalnego działania praw podstawowych (vermittelnde Drittwirkungslehre) ${ }^{36}$. W świetle tej koncepcji horyzontalne działanie praw podstawowych w pierwszej kolejności powinno być rozumiane jako wskazówka dla ustawodawcy, aby zawsze, stanowiąc prawo, brał pod uwagę prawa podstawowe. $Z$ kolei sądy w świetle tej koncepcji powinny uwzględniać prawa podstawowe

\footnotetext{
34 BGE 118 la 46,4 C.

35 R.A. Rhinow, Die Bundesverfassung 2000: eine Einführung, Basel 2000. s. 153; T. Fleiner-Gerster, A. Misic, N. Töpperwien, Swiss Constitutional..., s. 209.

36 P. Egli, Drittwirkung von Grundrechten, s. 150 i 197; G. Müller, Die Drittwirkung..., s. 241-242; P. Saladin, Grundrechte und Privatrechtsordnung, s. 382384 .
} 
zgodnie z założeniami teorii pośredniego horyzontalnego działania, czyli odwoływać się do nich w procesie wykładni klauzul generalnych i pojęć niedookreślonych. W Szwajcarii przyjmuje się jednak, że wykładnia prokonstytucyjna nie zawsze jest wystarczająca dla zapewnienia prawom konstytucyjnym skutecznej ochrony. Sądy, jeśli okaże się, że przepisy prawa prywatnego, które miałyby zostać przezeń zastosowane, naruszają lub ograniczają prawa podstawowe i wykładnia prokonstytucyjna nie jest w stanie zmienić tego stanu rzeczy, wówczas - jak przyjmuje szwajcarska doktryna prawa ${ }^{37}$ - w drugiej kolejności (als sekundärer Ansatz) powinny sięgnąć do koncepcji bezpośredniego horyzontalnego działania praw podstawowych. Ta ostatnia koncepcja może być również stosowana wtedy, gdy przepis konstytucyjny wyraźnie to umożliwia. Jedynym przepisem tak działającym był wspomniany wcześniej art. 4 ust. 2 Konstytucji Szwajcarii z 1874 r., będący odpowiednikiem art. 8 ust. 1 Knstytucji Szwajcarii z 1999 r. Kluczowe znaczenie dla szwajcarskiej koncepcji vermittelnde Drittwirkung Lehre ma zatem akceptacja poglądu o zróżnicowanym działaniu praw podstawowych w stosunkach horyzontalnych, przy czym każdorazowo obowiązek zapewnienia takiego działania spoczywa na państwie.

P. Egli twierdzi, że Sąd Federalny w swoim orzecznictwie ową koncepcję pośredniczącego horyzontalnego działania praw podstawowych przyjął za swoją własną, mimo wcześniejszego nieprzychylnego stanowiska względem koncepcji bezpośredniego horyzontalnego działania, która - choć w ograniczonym zakresie - stanowi element koncepcji szwajcarskiej ${ }^{38}$. Sąd Federalny podkreśla jednak, że uwzględnianie - w dalszej kolejności - skutku bezpośredniego działania praw podstawowych może mieć miejsce tylko wówczas, gdy przepisy prawa prywatnego naruszają istotę praw podstawowych albo gdy istotny dla praw podstawowych zakres $w$ ogóle nie jest regulowany lub jest regulowany w sposób niekompletny ${ }^{39}$.

37 P. Egli, Drittwirkung von Grundrechten, s. 150, 197; P. Sala din, Grundrechte und Privatrechtsordnung, s. 383-384.

38 P. Egli, Drittwirkung von Grundrechten, s. 151.

39 Ibidem. 
7. KONCEPCJA OBOWIAZZKÓW OCHRONNYCH PAŃSTWA W STOSUNKACH HORYZONTALNYCH

Dużym uznaniem w szwajcarskiej doktrynie prawa i judykaturze cieszy się również koncepcja obowiązków ochronnych państwa, która wzorowana jest na analogicznych koncepcjach stosowanych przez niemiecki Federalny Sąd Konstytucyjny oraz Europejski Trybunał Praw Człowieka. Zgodnie $z$ tą koncepcją państwo zobowiązane jest chronić prawa podstawowe przed zagrożeniami i naruszeniami ze strony podmiotów prywatnych. Szwajcarska doktryna prawa stara się unikać pojęcia pozytywnych obowiązków państwa, które używa ETPCz, a to z uwagi na jego szeroki zasięg, obejmujący zarówno obowiązek ochrony praw podstawowych, jak i obowiązek ich urzeczywistniania $^{40}$. W praktyce zamiast pojęcia obowiązków pozytywnych stosowane jest zatem pojęcie obowiązków ochronnych. BIDI. Jag.

Jeśli chodzi o podstawy konstytucyjne tej koncepcji, to ogólny obowiązek ochrony praw podstawowych, który ciąży na organach władzy publicznej, wywodzony jest ze wspomnianego wcześniej art. 35 ust. 1 BV i ujętego w nim nakazu urzeczywistniania praw podstawowych w całym porządku prawnym. Obowiązki ochronne państwa w sferze stosunków horyzontalnych są jednak również wywodzone z art. 2 Konstytucji, statuującego zasadę, zgodnie z którą Konfederacja Szwajcarska chroni wolność i prawa narodu. Obowiązki dotyczące ochrony konkretnych praw lub wolności wywodzone są natomiast z przepisów, które owe prawa i wolności statuują. W tym zakresie najczęściej wskazuje się w literaturze przedmiotu na trzy takie przepisy, tj. art. 7, art. 11 ust. 1 i art. 13 ust. 2 BV.

Zgodnie z art. 7 BV godność człowieka należy szanować i chronić. Przepis ten otwiera rozdział poświęcony prawom podstawowym i jest pierwszym przepisem takie prawo wyrażającym ${ }^{41}$. W doktrynie zwraca się uwagę na to, że art. 7 BV - w przeciwieństwie do art. 1

\footnotetext{
40 Na temat powodów zob. ibidem, s. 158.

4 R.A. Rhinow, Konstytucja Federalna Konfederacji Szwajcarskiej, [w:] Z. Czeszejko-Sochacki (red. nauk.), Konstytucja Federalna Szwajcarskiej Konfederacji
} 
ust. 1 Konstytucji RFN z 1949 r. - nie proklamuje expressis verbis zasady nienaruszalności godności człowieka ${ }^{42}$. Ta ostatnia zasada, w świetle poglądów niemieckiej doktryny i judykatury, nadaje godności absolutny charakter, przesądzając jednocześnie o tym, że obowiązek poszanowania godności człowieka jest adresowany nie tylko do państwa i jego organów, ale również do podmiotów prywatnych. Brak zasady nienaruszalności godności człowieka w treści art. 7 BV nie oznacza jednak, że w szwajcarskich realiach konstytucyjnych zasada ta nie obowiązuje. W doktrynie wskazuje się, że obowiązek poszanowania godności człowieka jest kompilacją obowiązków obronnych i ochronnych państwa w stosunku do praw podstawowych.

Kolejnym przepisem, który formułuje obowiązki ochronne państwa w sferze stosunków horyzontalnych, jest art. 11 ust. 1 BV. Przyznaje on dzieciom i młodzieży możliwość żądania szczególnej ochrony ich nietykalności oraz wspierania ich rozwoju. W doktrynie na gruncie tego przepisu oba roszczenia traktuje się rozdzielnie. Jeśli chodzi o roszczenie dotyczące wspierania rozwoju dzieci i młodzieży, to ta część przepisu stanowi normę programową, która adresowana jest do ustawodawcy. Natomiast jeśli chodzi o roszczenie o szczególną ochronę nietykalności dzieci i młodzieży, to wynika z niego obowiązek organów państwowych do zapewnienia takiej ochrony zarówno przed naruszeniami ze strony państwa, jak i podmiotów prywatnych ${ }^{43}$.

Obowiązki ochronne państwa wywodzone są również z art. 13 ust. 2 BV, który przyznaje każdemu roszczenie o ochronę przed bezprawnym przetwarzaniem jego danych osobowych. Przepis ten niewątpliwie zawiera prawo obronne działające przeciwko państwu, a zatem w stosunkach wertykalnych. Powszechnie przyjmuje się jednak, że wyrażony w nim zakaz bezprawnego przetwarzania danych osobowych adresowany jest nie tylko do państwa, ale i podmiotów

z 1999 r. i Konstytucja Rzeczypospolitej Polskiej z 1997 r. Materiaty z Polsko-Szwajcarskiego Sympozjum z 26-27 października 2000 r., Białystok 2001, s. 43.

42 P. Egli, Drittwirkung von Grundrechten, s. $16_{1}$.

4) Ibidem, S. 164. 
prywatnych. Wyrażającemu go art. 13 ust. 2 BV przypisuje się bowiem pośrednie horyzontalne działanie $\mathrm{e}^{44}$. Od owego zakazu bezprawnego przetwarzania danych osobowych należy jednak odróżnić nakaz ochrony przed tego typu bezprawnym działaniem. Nie ma wątpliwości co do tego, że żądanie zapewnienia takiej ochrony może być kierowane tylko pod adresem państwa i jego organów.

We wczesnym orzecznictwie szwajcarskiego Sądu Federalnego obowiązki ochronne państwa ograniczano jedynie do niektórych praw podstawowych, takich jak wolność sumienia, wolność słowa, wolność zgromadzeń i wolność zrzeszeń. Podkreślano bowiem, że skuteczne gwarantowanie tych wolności wymaga nie tylko obrony przed naruszeniami ze strony państwa, ale również zapewnienia ochrony przed zagrożeniami ze strony podmiotów prywatnych ${ }^{45}$. Stąd wolności te nie mają jedynie charakteru negatywnego, lecz również charakter pozytywny, ponieważ zobowiązują państwo do umożliwienia ich adresatom pełnego i skutecznego korzystania z nich. Podobnie przyjmuje się, że własność prywatna powinna być chroniona nie tylko przed naruszeniami ze strony państwa, ale również ze strony podmiotów prywatnych. Obowiązki ochronne najczęściej formułowane są $\mathrm{w}$ odniesieniu do praw osobistych ${ }^{46}$. Wśród praw politycznych przepisem ustanawiającym obowiązki ochronne jest art. 34 ust. 2. Wynika z niego obowiązek ochrony możliwości swobodnego kształtowania woli oraz niesfałszowanego oddania głosu.

Na koniec rozważań dotyczących koncepcji Drittwirkung w szwajcarskich realiach konstytucyjnych warto wskazać, że w doktrynie prawa prezentowany jest pogląd, zgodnie $\mathbf{z}$ którym Drittwirkung stanowi szczególny przypadek obowiązków ochronnych państwa ${ }^{47}$. W wypadku bezpośredniego horyzontalnego działania państwo jest zobowiązane do zagwarantowania praw podstawowych jako bezpośrednio

\footnotetext{
4 D. Blonski, M. Florczak-Wą tor, Problem horyzontalnej skuteczności prawa do ochrony danych osobowych $w$ swietle przepisów konstytucyinych Polski i Szwajcarii, „Przegląd Sejmowy” 2015, nr 1, s. 93.

45 P. Egli, Drittwirkung von Grundrechten, s. 172-173.

46 Zob. BGE 126 II 300, 314.

47 R.A. Rhinow, M. Schefer, Schweizerisches..., s. 236.
} 
działających roszczeń prawnych między podmiotami prywatnymi. Z kolei w wypadku pośredniego horyzontalnego działania sędzia, jako organ państwa, wykonując spoczywający na nim obowiązek ochrony, zobowiązany jest do interpretowania i stosowania norm prawa prywatnego $\mathrm{z}$ uwzględnieniem praw podstawowych. Tym samym koncepcje bezpośredniego i pośredniego horyzontalnego działania staja się szczególną formą realizacji koncepcji obowiązków ochronnych państwa.

\section{WNIOSKI KOŃCOWE}

Podsumowując powyższe rozważania, należy stwierdzić, że zasięg dyskusji o horyzontalnym działaniu praw podstawowych w Szwajcarii jest zdeterminowany w pierwszej kolejności przez art. $35 \mathrm{BV}$. Przepis ten przewiduje, że prawa podstawowe muszą być urzeczywistniane w całym porządku prawnym, zaś każdy, kto wykonuje zadania państwowe, jest nimi związany, jak również jest zobowiązany przyczyniać się do ich realizacji. Ponadto, stosownie do treści tego przepisu, władze publiczne są zobowiązane do dbania o to, by prawa podstawowe, o ile do tego się nadają, także między podmiotami prywatnymi były stosowane. W szwajcarskiej doktrynie prawa dominuje przekonanie, że prawa podstawowe działają w stosunkach między podmiotami prywatnymi pośrednio, ewentualnie zgodnie z założeniami pośredniczącej koncepcji horyzontalnej. Koncepcja bezpośredniego horyzontalnego działania tych praw znajduje zastosowanie tylko wówczas, gdy Konstytucja Szwajcarii z 1999 r. tak stanowi. Jedynym przepisem bezspornie wykazującym takie działanie jest wspomniany art. 8 ust. 3 BV. 
In Switzerland the discussion on the issue of the horizontal application of basic rights remains very much under the influence of German legal doctrine and jurisprudence. In the Constitution of 1999 this issue is directly regulated by Art. 35, which is divided into three sections; these sections try to explain the mode and scope of the application of human rights to horizontal relations. According to Art. 35 of the Swiss Constitution: 1) fundamental rights must be upheld throughout the legal system, 2) whoever acts on behalf of the State is bound by fundamental rights and is under a duty to contribute to their implementation, 3) the authorities shall ensure that fundamental rights, where appropriate, apply to relations among private persons.

Art. $35 \mathrm{sec}$. 3 of the Swiss Constitution excludes, as a general rule, the possibility that there can be a direct horizontal application of basic rights. A direct horizontal application is possible only exceptionally, in situations when such an application of basic rights can be deduced from a constitutional provision. As an example of such a constitutional regulation, one can point to Art. $8 \mathrm{sec}$. 3 sentence 3 of the Swiss Constitution, according to which a woman and a man have the right to equal payment for equal jobs. Some proponents of the legal doctrine claim that a direct horizontal application of basic rights can also be found in two other constitutional provisions, namely Art. $17 \mathrm{sec}$. 3 (which protects the confidentiality of press sources) and Art. $28 \mathrm{sec} .3$ (concerning the right to organize a strike or lockout).

This view, which excludes in principle the idea of the direct horizontal application of basic rights, is also shown in the case law of the Swiss Federal Court. Initially this Court accepted the direct horizontal application of some rights, such as freedom of religion or freedom of expression, but it later changed its mind. In its 1992 judgment in the Info-Secta case, the Federal Court said that freedom of religion only protects an individual against infringements by the State and it does not work directly against other individuals.

In Switzerland it is commonly accepted that basic rights are applied indirectly as directions for State authorities in the processes of making and interpreting the law. The duty to ensure the realization of basic rights in the whole legal order is imposed primarily on the legislator, who should 
respect those rights when issuing private law provisions. Next, the same duty to ensure the realization of basic rights in the whole legal order lies on the State authorities when applying the law, and particularly on the courts, which are obliged to respect those rights in the interpretation of uncertain terms and general clauses.

In Switzerland the doctrine of the protective duties of the State is also commonly accepted. This doctrine is modeled on analogous doctrines applied by the German Federal Constitutional Court and the European Court of Human Rights and Fundamental Freedoms. According to this principle, the State has a duty to protect basic rights against private infringements. The general obligation to protect basic rights, which is imposed on the organs of public authorities, is derived from the aforementioned Art. $35 \mathrm{sec} 1$ of the Swiss Constitution and is expressed in the demand made in this section for the realization of basic rights in the whole legal order. The State's protective obligations in the sphere of horizontal relations are also derived from Art. 2 of the Swiss Constitution, according to which the Swiss Federation shall protect the liberty and rights of the people and safeguard the independence and security of the country. Particular obligations concerning concrete rights and freedoms derive from the constitutional provisions that set out those rights and freedoms. In this matter three provisions are most commonly pointed to in the legal doctrine, namely Art. 7 ("Human dignity must be respected and protected"), Art. 11 sec. 1 ("Children and young people have the right to the special protection of their integrity and to the encouragement of their development") and Art. $13 \mathrm{sec}$. 2 ("Every person has the right to be protected against the misuse of their personal data").

\section{BIBLIOGRAFIA}

Biaggini G., Bundesverfassung der Schweizerischen Eidgenossenschaft und Auszüge aus der EMRK, den UNO-Pakten sowie dem BGG, Zürich 2007. Biaggini G., Gächter T., Kiener R. (Hrsg.), Staatsrecht, Zürich 2011. Blonski D., Florczak-WĄToR M., Problem horyzontalnej skuteczności prawa do ochrony danych osobouych $w$ swietle przepisów konstytucyjnych Polski i Szwajcarii, "Przegląd Sejmowy" 2015, nr 1. 
EgLI P., Drittwirkung von Grundrechten. Zugleich ein Beitrag zur Dogmatik der grundrechtlichen Schutzpflichten im Schweizer Recht, Zürich 2002. Fleiner-Gerster T., Misic A., Töpperwien N., Swiss Constitutional Law, Bern 2005.

Göksu T., Drittwirkung der Grundrechte im Bereich des Persönlichkeitsschutzes, "Schweizerische Juristen-Zeitung" 2002, Nr. 4.

Haller W., Kölz A., Allgemeines Staatsrecht. Ein Grundriss, Basel 2004.

Kiener R., Kälin W., Grundrechte, Bern, 2007.

Müller G., Die Drittwirkung der Grundrechte, Schweizerisches Zentralblatt für Staats- und Gemeindevenvaltung, 1978, Nr. 79.

MülLeR J.P., Elemente einer schweizerischen Grundrechtstheorie, Bern 1982. MÜLLER J.P., Zur sog. subjektiv- und objektivrechtlichen Bedeutung der Grundrechte: rechtsvergleichende Bemerkungen aus Schweizer Sicht, "Der Staat" 1990.

Rhinow R.A., Die Bundesverfassung 2000: eine Einführung, Basel 2000.

Rhinow R.A., Konstytucja Federalna Konfederacji Szwajcarskiej, [w:] Z. CzESZEJKo-SochaCKI (red. nauk.), Konstytucja Federalna Szwajcarskiej Konfederacji z 1999 r. i Konstytucja Rzeczypospolitej Polskiej z 1997 r. Materiały z Polsko-Szwajcarskiego Sympozjum z 26-27 paździemika 2000 r., Białystok 2001.

Rhinow R.A., Scheffer M., Schweizerisches Verfassungsrecht, Basel 2009. SAladin P., Die Kunst der Verfassungserneuerung: Schriften zur Verfassungsreform 1968-1996, Basel 1998.

Saladin P., Grundrechte und Privatrechtsordnung. Zum Streit um die sog. "Drittwirkung» der Grundrechte, "Schweizerische Juristen-Zeitung" 1988, Nr. 15 . 
